\title{
JURE GAŠPARIČ: SLS POD KRALJEVO DIKTATURO (DIKTATURA KRALJA ALEKSANDRA IN POLITIKA SLOVENSKE LJUDSKE STRANKE $V$ LETIH 1929-1935)
}

Ljubljana: Modrijan, 2007, 304 strani.

Pričujoča knjiga je nastala kot doktorska disertacija, ki jo je avtor zagovarjal le leto pred knjižnim izidom. Delo je v pretres vzelo pet burnih let medvojnega obdobja, ki se je začelo z diktaturo kralja Aleksandra in prepovedjo obstoja vseh nacionalnih političnih strank ter se izteklo v ponovno obuditev večstrankarskega političnega življenja in predstavlja delovanje Slovenske ljudske stranke (SLS), ki je najmočneje zaznamovala družbeno-politično dogajanje na Slovenskem. Njeno delovanje knjiga postavlja $\mathrm{v}$ širši kontekst novonastalega državno političnega okvira, Kraljevine Jugoslavije. Ta je bila od samih začetkov obsojena na nestabilen in majav razvoj, ki so se pridružile politične krize. Kljub stalnim »izrednim razmeram « pa je SLS ostajala zmagovalka in najpomembnejši politični akter medvojnega obdobja. Knjiga je razdeljena na šest tematsko in vsebinsko povezanih poglavij, ki kronološko pripo- vedujejo zgodbo o neusmiljenih političnih bojih in ohranitvi oblasti.

$\mathrm{V}$ uvodu avtor predstavi zgodovinske razmere in oriše družbenopolitično stanje na Slovenskem pred nastankom novega jugoslovanskega državnega okvira. Posebna pozornost je namenjena razvoju in uveljavitvi dveh takratnih najmočnejših političnih gibanj, katoliški Slovenski ljudski stranki in Liberalni stranki. Zgodovinski razvoj obeh političnih strank je postavljen v širši geografski kontekst treh slovenskih pokrajin (Goriške, Kranjske, Štajerske). Strnjen in zelo pregleden način, $\mathrm{z}$ omenjanjem in predstavljanjem dodatnih virov, služi kot uvod v kasnejše dogajanje in predvsem politični razvoj omenjenih dveh skupin v medvojnem obdobju.

$\mathrm{V}$ nadaljevanju so predstavljeni vzroki, ki so pripeljali k uvedbi diktature in njene posledice na družbeno-politično dogajanje $\mathrm{v}$ takratni 
kraljevini in še natančneje v Sloveniji. V tekstu lahko sledimo političnim dejanjem takratnega režima. Predvsem je zanimiva predstavitev sprememb na pravnem področju. Tu nam avtor zelo natančno predstavi število spremenjenih oziroma na novo sprejetih zakonov, ki so se $\mathrm{v}$ nasprotju $\mathrm{z}$ minulim desetletjem, sprejemali $\mathrm{v}$ precej večjem številu. Hkrati lahko zasledujemo politični razvoj in politično delovanje vidnih članov Slovenske ljudske stranke kljub razpustitvi politične stranke. Ti tako sodelujejo pri oblikovanju novega političnega režima $\mathrm{v}$ takratni Kraljevini Jugoslaviji. Vodil naj bi jih pragmatizem, ki ga pisec poimenuje »Realpolitik«. Tovrstna instrumentalna politika pa je spodbudila pomisleke tudi v samem katoliškem gibanju. Nove politične ideje in načrti, ki so jih gojila različna društva in skupine, ki so se oblikovala ob že omenjeni razpustitvi stranke, so tako poglobila razkol v politični stranki v zadnjih letih medvojnega obdobja.

Slovenska ljudska stranka navkljub tako pravnim omejitvam kot pritiskom oblasti, preko različnih društev ostaja viden dejavnik slovenskega političnega življenja. V kontekstu političnih bojev med obema najmočnejšima političnima taboroma na Slovenskem ji je uspelo zadržati svoje pozicije in dolgoročno tudi utrditi svoj položaj. Tovrstno trditev podpira zlasti ponesrečen katoliški prevzem Kmečke družbe in uspešen razpust te iste družbe in preusmeritev njenega delovanja $\mathrm{v}$ številna društva.

Pomisleki v samem katoliškem gibanju in vladno zasledovanje cilja o oblikovanju enega samega jugoslovanskega naroda je končno spodbudilo SLS, da se je umaknila v opozicijo. Vzroke za umik nekdanje Slovenske ljudske stranke v politično opozicijo avtor predstavi, kot kompleksno dejanje, pogojeno z družbeno-politično sliko takratne kraljevine in Dravske banovine, pa tudi z novimi političnimi smernicami beograjskega dvora, ki je v državi ponovno želel uveljaviti ustavnost. Umik SLS v opozicijo pred volitvami pomeni ponovno obuditev starih strankarskih nasprotij, predvsem pa številnih predvolilnih manipulacij in malverzacij. Avtor podrobneje analizira politične vzroke za zavrnitev sodelovanja nekdanje Slovenske ljudske stranke na volitvah, iz katerih je katoliško politično gibanje na Slovenskem izšlo kot zmagovalec. K temu so pripomogli dogodki, ki jih je avtor še posebej osvetlil. Mednje zagotovo sodi tudi politično praznovanje 60-letnice voditelja stranke 
dr. Antona Korošca. To je botrovalo političnemu dogajanju, ki je pustilo velik pečat na politično življenje na Slovenskem. Med drugim so omenjeni dogodki, povzročili tudi notranji razkroj v nekdanji Slovenski ljudski stranki. Pripomogli so k izoblikovanju struje, ki bo v bodočem političnega življenja odigral eno ključnih vlog v zgodovini Slovenije. Avtor nam zelo jasno predstavi posledice tovrstnih javnih manifestacij ob praznovanju dr. Antona Korošca in končni »izplen « političnega nasprotovanja tedanji oblasti.

Pod naslovom Koraki k vrnitvina oblast je jasno predstavljeno sosledje dogodkov, ki so pripeljali nekdanjo Slovensko ljudsko stranko ponovno na oblast, ki jo je zapustila leta 1931. $\mathrm{V}$ tem kontekstu je tako zanimiva zlasti predvolilna dejavnost političnih skupin in spremembe na upravno-političnem področju, ki so nastali kot posledica zasuka ob vrnitvi SLS na oblast. V delu avtor osvetli atentat na kralja Aleksandra. Posebej je potrebno izpostaviti avtorjevo natančno in zelo pregledno pojasnitev ter spretno vpletanje omenjenih pojasnil v celotno družbeno dogajanje v kraljevini, katere posledice so se občutile tudi na Slovenskem.

Avtorjevo zaključno poglavje $\mathrm{z}$ naslovom Vrnitev na oblast je po- svečeno pregledu družbeno-političnih dogodkov, ki so se zvrstili ob ponovni vrnitvi Antona Korošca na vrh ne le takratne slovenske, temveč tudi jugoslovanske politike. Posledično je to pomenilo tudi vrnitev Slovenske ljudske stranke, ki je tudi uradno postala pomemben politični dejavnik v monarhiji. V poglavju je kronološko predstavljen začetek konca vladanja vlade premiera Jevtića. Z izsiljenim odstopom treh ministrov je vlada padla, zamenjala jo je trojica Stojadinović-KorošecSpaho. V kontekstu tega »triumvirata « je tako zlasti predstavljen lik in delo notranjega ministra dr. Antona Korošca. Delo vsebinsko zelo jasno umesti delovanje slovenske politične stranke $\mathrm{v}$ kontekst jugoslovanskega prostora in pojasni vpliv posameznih političnih dogodkov na politične razmere v Sloveniji. Vprašanje, ki si ga na koncu zastavi avtor (Ali je omenjeni dogodek začetek novega vzpona ali začetek konca?), bo zagotovo prispevalo $\mathrm{k}$ natančnejši analizi delovanja SLS tudi med obema vojnama, ki je doslej nekoliko umanjkala, čeprav so posamezna dela osvetlila njeno delovanje zlasti do leta 1929. Odgovor avtorja je teza, da je nekdanja Slovenska ljudska stranka poosebljala politično voljo Slovencev in je $\mathrm{z}$ omenjenim 
družbeno-političnim kreditom, ki stavljena, kot tudi ne vloga vodje ga je nosila s seboj bila vedno ali- dr. Antona Korošca. Ali kot zapiše bi tistih, ki so z nedemokratičnimi avtor v Predgovoru: »Vsakokratno sredstvi prevzeli oblast. aktualno družbeno in politično oko-

Knjiga SLS pod kraljevo diktaturo avtorja, Jureta Gašpariča vsebinsko in strokovno zanimiva, ne samo za strokovno javnost temveč tudi za znanja željnega bralca. Avtor omenjene knjige namreč razkriva in predstavlja del slovenske zgodovine, ki ni bil nikoli natančneje predlje pač vedno generira raznovrstne interpretacije preteklosti, ki se tako od svojih predhodnic, kot med sabo včasih precej razlikujejo«. Vsekakor je $\mathrm{v}$ pričajočem delu zaobjeto in kritično analizirano več omenjenih resnic, kar da delu še dodatno težo, bralca pa spodbodi k še natančnejšemu branju. 